\title{
Front Matter: Volume 8742
}

, "Front Matter: Volume 8742," Proc. SPIE 8742, Ground/Air Multisensor Interoperability, Integration, and Networking for Persistent ISR IV, 874201 (24 June 2013); doi: 10.1117/12.2031807

Event: SPIE Defense, Security, and Sensing, 2013, Baltimore, Maryland, SPIE. United States 


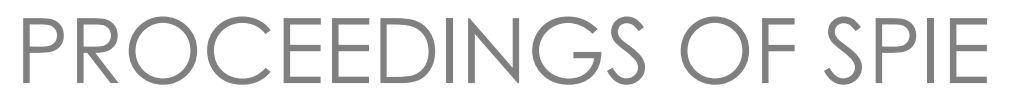

\section{Ground/Air Multisensor Interoperability, Integration, and Networking for Persistent ISR IV}

Tien Pham

Michael A. Kolodny

Kevin L. Priddy

Editors

29 April-2 May 2013

Baltimore, Maryland, United States

Sponsored and Published by

SPIE 
The papers included in this volume were part of the technical conference cited on the cover and title page. Papers were selected and subject to review by the editors and conference program committee. Some conference presentations may not be available for publication. The papers published in these proceedings reflect the work and thoughts of the authors and are published herein as submitted. The publisher is not responsible for the validity of the information or for any outcomes resulting from reliance thereon.

Please use the following format to cite material from this book:

Author(s), "Title of Paper," in Ground/Air Multisensor Interoperability, Integration, and Networking for Persistent ISR IV, edited by Tien Pham, Michael A. Kolodny, Kevin L. Priddy, Proceedings of SPIE Vol. 8742 (SPIE, Bellingham, WA, 2013) Article CID Number.

ISSN: 0277-786X

ISBN: 9780819495334

Published by

SPIE

P.O. Box 10, Bellingham, Washington 98227-0010 USA

Telephone +1 3606763290 (Pacific Time) Fax +1 3606471445

SPIE.org

Copyright (C) 2013, Society of Photo-Optical Instrumentation Engineers.

Copying of material in this book for internal or personal use, or for the internal or personal use of specific clients, beyond the fair use provisions granted by the U.S. Copyright Law is authorized by SPIE subject to payment of copying fees. The Transactional Reporting Service base fee for this volume is $\$ 18.00$ per article (or portion thereof), which should be paid directly to the Copyright Clearance Center (CCC), 222 Rosewood Drive, Danvers, MA 01923. Payment may also be made electronically through CCC Online at copyright.com. Other copying for republication, resale, advertising or promotion, or any form of systematic or multiple reproduction of any material in this book is prohibited except with permission in writing from the publisher. The CCC fee code is 0277-786X/13/\$18.00.

Printed in the United States of America.

Publication of record for individual papers is online in the SPIE Digital Library.

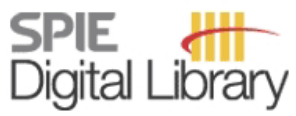

SPIEDigitalLibrary.org

Paper Numbering: Proceedings of SPIE follow an e-First publication model, with papers published first online and then in print and on CD-ROM. Papers are published as they are submitted and meet publication criteria. A unique, consistent, permanent citation identifier (CID) number is assigned to each article at the time of the first publication. Utilization of CIDs allows articles to be fully citable as soon as they are published online, and connects the same identifier to all online, print, and electronic versions of the publication. SPIE uses a six-digit CID article numbering system in which:

- The first four digits correspond to the SPIE volume number.

- The last two digits indicate publication order within the volume using a Base 36 numbering

system employing both numerals and letters. These two-number sets start with 00, 01, 02, 03, 04, $05,06,07,08,09,0 A, 0 B \ldots$. 0Z, followed by 10-1Z, 20-2Z, etc.

The CID Number appears on each page of the manuscript. The complete citation is used on the first page, and an abbreviated version on subsequent pages. Numbers in the index correspond to the last two digits of the six-digit CID Number. 


\section{Contents}

vii Conference Committee
ix Introduction

DATA-TO-DECISIONS: JOINT SESSION WITH CONFERENCES 8742 AND 8758

874202 Context-rich semantic framework for effective data-to-decisions in coalition networks [8742-2]

K. Grueneberg, IBM Thomas J. Watson Research Ctr. (United States); G. de Mel, IBM Thomas J. Watson Research Ctr. (United States) and U.S. Army Research Lab. (United States); D. Braines, IBM United Kingdom Ltd. (United Kingdom); X. Wang, S. Calo, IBM Thomas J. Watson Research Ctr. (United States); T. Pham, U.S. Army Research Lab. (United States)

874203 A system architecture for decision-making support on ISR missions with stochastic needs and profit [8742-3]

N. Hu, The Pennsylvania State Univ. (United States); D. Pizzocaro, Cardiff Univ. (United Kingdom); T. La Porta, The Pennsylvania State Univ. (United States); A. Preece, Cardiff Univ. (United Kingdom)

\section{ISR INTEROPERABILITY: UGS SWG AND TERRA HARVEST I}

874204 Using advanced manufacturing to produce unmanned aerial vehicles: a feasibility study [8742-41]

S. Easter, J. Turman, D. Sheffler, Univ. of Virginia (United States); M. Balazs, J. Rotner, The MITRE Corp. (United States)

874206 The THOSE remote interface [8742-5]

K. Klawon, J. Gold, K. Bachman, Univ. of Dayton Research Institute (United States)

874207 How to use the THOSE GUI [8742-6]

K. Klawon, D. Humeniuk, N. Marcucci, Univ. of Dayton Research Institute (United States)

874208 Development of Terra Harvest compliant plug-ins for McQ Unattended Ground Sensors (UGS) [8742-7]

B. W. Roeder, R. C. Fish, McQ Inc. (United States)

\section{COALITION INTEROPERABILITY}

8742 OC U.K. MoD Land Open Systems Architecture and coalition interoperability with the U.S. [8742-12] G. Pearson, Defence Science and Technology Lab. (United Kingdom); M. Kolodny, U.S. Army Research Lab. (United States) 
8742 OD Practical experience in deploying and controlling the data sharing interoperability layer at the U.K. Land Open Systems Architecture (LOSA) field trials in October 2012 [8742-13] F. Bergamaschi, D. Conway-Jones, IBM United Kingdom Ltd. (United Kingdom); G. Pearson, Defence Science and Technology Lab. (United Kingdom)

8742 OE Future Interoperability of Camp Protection Systems (FICAPS) [8742-14]

S. Caron, Direction Générale de l'Armement (France); R. Gündisch, Wehrtechnische Dienststelle für Schutz- und Sondertechnik (Germany); A. Marchand, Thales TDA Armements S.A.S. (France); K.-H. Stahl, Rheinmetall Defence Electronics GmbH (Germany)

8742 OF Coalition Warfare Program (CWP): secure policy controlled information query and dissemination over a Bices network [8742-15]

A. Toth, T. Pham, U.S. Army Research Lab. (United States); T. Karr, Defense Intelligence Agency (United Kingdom); G. Bent, D. Harries, A. Knox, IBM United Kingdom Ltd. (United Kingdom)

8742 OG Flexible procedural interoperability across security and coalition boundaries using rapidly reconfigurable boundary protection definitions [8742-16]

N. Peach, 2iC Ltd. (United Kingdom)

\section{SCIENCE OF AUTONOMY}

$8742 \mathrm{OH}$ The science of autonomy: integrating autonomous systems with the ISR enterprise [8742-17] G. S. Creech, Office of the Under Secretary of Defense for Intelligence (United States)

\section{NATO SET-189 BATTLEFIELD ACOUSTICS}

8742 0J Hostile fire indicator threat data collection for helicopter-mounted applications [8742-19] P. Naz, S. Hengy, S. De Mezzo, French-German Research Institute of Saint-Louis (France)

8742 OK Source localization results for airborne acoustic plafforms in the 2010 Yuma Proving Ground test [8742-20]

V. E. Ostashev, Univ. of Colorado at Boulder (United States) and NOAA (United States);

S. L. Collier, C. G. Reiff, U.S. Army Research Lab. (United States); S. Cheinet, French-German Research Institute of Saint-Louis (France); D. A. Ligon, U.S. Army Research Lab. (United States); D. K. Wilson, U.S. Army Engineer Research and Development Ctr. (United States); J. M. Noble, W. C. Alberts, U.S. Army Research Lab. (United States)

$8742 \mathrm{OL} \quad$ River as a part of ground battlefield [8742-21]

M. S. Vračar, I. Pokrajac, P. Okiljević, Military Technical Institute (Serbia)

\section{PERSISTENT ISR}

$87420 \mathrm{M}$ Air route selection for improved air-to-ground situation assessment [8742-22]

M. Oispuu, M. Sciotti, A. Charlish, Fraunhofer FKIE (Germany)

874200 Clustering of estimated spatial locations in networked sensors [8742-24]

I. P. Pokrajac, P. Okiljevic, M. Vracar, Military Technical Institute (Serbia)

iv 
8742 OP Application of inexpensive, low-cost, low-bandwidth silhouette profiling UGS systems to current remote sensing operations [8742-25]

E. Y. Haskovic, S. Walsh III, G. Cloud, R. Winkelman, Brimrose Technology Corp. (United

States); Y. Jia, S. Vishnyakov, F. Jin, Brimrose Corp. of America (United States)

NETWORKING FOR NETCENTRIC WARFARE: JOINT SESSION WITH CONFERENCES 8742 AND 8754

$87420 Q \quad$ A key management scheme for tiered wireless sensor network with self-healing capability [8742-26]

M. Wang, Communications Research Ctr. Canada (Canada); H. Tang, Defence Research and Development Canada, Ottawa (Canada); F. R. Yu, Carleton Univ. (Canada)

8742 OR A data collection decision-making framework for a multi-tier collaboration of heterogeneous orbital, aerial, and ground craft [8742-27]

J. Straub, Univ. of North Dakota (United States)

\section{DISTRIBUTED/DECENTRALIZED SENSOR NETWORKS AND DATA FUSION}

8742 OS On-line data validation in distributed data fusion [8742-28]

J. Preden, Tallinn Univ. of Technology (Estonia); J. Llinas, Univ. at Buffalo (United States); G. Rogova, Encompass Consulting (United States); R. Pahtma, L. Motus, Tallinn Univ. of Technology (Estonia)

8742 OT Low frame rate video target localization and tracking testbed [8742-31]

Y. Pang, Temple Univ. (United States); D. Shen, G. Chen, Intelligent Fusion Technology, Inc. (United States); P. Liang, Temple Univ. (United States); K. Pham, E. Blasch, Air Force Research Lab. (United States); Z. Wang, Intelligent Fusion Technology, Inc. (United States); H. Ling, Temple Univ. (United States)

\section{COLLABORATIVE INFORMATION PROCESSING/SHARING}

8742 OV Acoustic network event classification using swarm optimization [8742-32] J. Burman, Intelligent Recognition Systems (United States)

8742 OW Virtual GEOINT Center: C2ISR through an avatar's eyes [8742-33] M. Seibert, T. Tidbal, M. Basil, T. Muryn, J. Scupski, Tec^Edge Innovation and Collaboration Ctr. (United States); R. Williams, Tec^Edge Innovation and Collaboration Ctr. (United States) and Air Force Research Lab. (United States)

8742 0X Dynamically allocated virtual clustering management system [8742-29] K. Marcus, U.S. Army Research Lab. (United States); J. Cannata, R Systems NA, Inc. (United States)

8742 OY Characterization and definition of a software stack for a reference experimental framework [8742-34]

A. Toth, U.S. Army Research Lab. (United States); F. Bergamaschi, IBM United Kingdom Ltd. (United Kingdom) 
$87420 Z$ Managing ISR sharing policies at the network edge using Controlled English [8742-35]

C. Parizas, D. Pizzocaro, A. Preece, Cardiff Univ. (United Kingdom); P. Zerfos, IBM Thomas J. Watson Research Ctr. (United States)

874210 Diagnosing degradation of services in hybrid wireless tactical networks [8742-36] S. Tati, The Pennsylvania State Univ. (United States); P. Novotny, Imperial College London (United Kingdom); B. J. Ko, IBM Thomas J. Watson Research Ctr. (United States); A. Wolf, Imperial College London (United Kingdom); A. Swami, U.S. Army Research Lab. (United States); T. La Porta, The Pennsylvania State Univ. (United States)

\section{COLLABORATIVE INFORMATION PROCESSING/SHARING VIA MOBILE DEVICES}

874211 A collaborative smartphone sensing platform for detecting and tracking hostile drones [8742-37]

S. K. Boddhu, Qbase (United States); M. McCartney, Wright State Univ. (United States); O. Ceccopieri, R. L. Williams, Tec^Edge Innovation and Collaboration Ctr. (United States) and Air Force Research Lab. (United States)

874212 Smartphones for distributed multimode sensing: biological and environmental sensing and analysis [8742-38]

T. Feitshans, Ohio Nothern Univ. (United States); R. Williams, Tec^Edge Innovation and Collaboration Ctr. (United States) and Air Force Research Lab. (United States)

874213 Context-aware event detection smartphone application for first responders [8742-39] S. K. Boddhu, R. P. Dave, Qbase (United States); M. McCartney, J. A. West, Wright State Univ. (United States); R. L. Williams, Tec^Edge Innovation and Collaboration Ctr. (United States) and Air Force Research Lab. (United States)

Author Index 


\title{
Conference Committee
}

\author{
Symposium Chair
}

Kenneth R. Israel, Major General (USAF Retired) (United States)

Symposium Cochair

David A. Whelan, Boeing Defense, Space, and Security (United States)

Conference Chair

Tien Pham (United States)

Conference Cochairs

Michael A. Kolodny, U.S. Army Research Laboratory (United States)

Kevin L. Priddy, Air Force Research Laboratory (United States)

Conference Program Committee

Jacques Bédard, Defence Research and Development Canada, Valcartier (Canada)

Robert Heathcock, U.S. Defense Intelligence Agency (United States)

Gavin Pearson, Defence Science and Technology Laboratory (United Kingdom)

Stephen G. Perry, MTC Services Corporation (United States)

Andre Samberg, Sec-Control Finland Ltd. (Finland)

King K. Siu, U.S. Army Armament Research, Development and Engineering Center (United States)

Raja Suresh, General Dynamics Advanced Information Systems (United States)

Graeme P. van Voorthuijsen, TNO Defence, Security and Safety (Netherlands)

Robert L. Williams, Air Force Research Laboratory (United States)

\section{Session Chairs}

1 Data-to-Decisions: Joint Session with Conferences 8742 and 8758

David L. Hall, The Pennsylvania State University (United States)

James Llinas, University at Buffalo (United States)

Tien Pham (United States) 
2 ISR Interoperability: UGS SWG and Terra Harvest I

Michael A. Kolodny, U.S. Army Research Laboratory (United States)

3 ISR Interoperability: UGS SWG and Terra Harvest II

Michael A. Kolodny, U.S. Army Research Laboratory (United States)

4 Coalition Interoperability

Michael A. Kolodny, U.S. Army Research Laboratory (United States)

5 Science of Autonomy

Tien Pham (United States)

Gregory S. Creech, Office of the Under Secretary of Defense for Intelligence (United States)

6 NATO SET-189 Battlefield Acoustics

Bob Madahar, Defence Science and Technology Laboratory (United Kingdom)

7 Persistent ISR

Tien Pham (United States)

8 Networking for Netcentric Warfare: Joint Session with Conferences 8742 and 8754

Raja Suresh, General Dynamics Advanced Information Systems (United States)

Tien Pham (United States)

9 Distributed/Decentralized Sensor Networks and Data Fusion

Tien Pham (United States)

10 Collaborative Information Processing/Sharing

Flavio Bergamschi, IBM United Kingdom Ltd. (United Kingdom)

11 Collaborative Information Processing/Sharing via Mobile Devices

Flavio Bergamschi, IBM United Kingdom Ltd. (United Kingdom) 
Panel Discussion on Decision-Driven Analysts: Joint Panel with Conferences 8742 and 8758

David L. Hall, The Pennsylvania State University (United States)

James Llinas, University at Buffalo (United States)

Bob Madahar, Defence Science and Technology Laboratory (United Kingdom)

Tien Pham (United States)

Panel Discussion on Science of Autonomy

Gregory S. Creech, Moderator, Office of the Under Secretary of Defense for Intelligence (United States)

Robert Kohout, iRobot, Inc. (United States)

Richard Davis, Office of the Under Secretary of Defense for Intelligence (United States)

Mark Chapin, Draper Laboratory (United States)

Kristina Czuchlewski, Sandia National Laboratories (United States) 
Proc. of SPIE Vol. $8742874201-10$

Downloaded From: https://www.spiedigitallibrary.org/conference-proceedings-of-spie on 26 Apr 2023 Terms of Use: https://www.spiedigitallibrary.org/terms-of-use 


\section{Introduction}

The Ground/Air Multisensor Interoperability, Integration, and Networking for Persistent ISR conference focuses on research and technology for persistent surveillance applications. More specifically, the conference focuses on how to integrate and network disparate ISR elements: (i) to enable disparate sensor and information sources to be combined, fused, and/or discovered autonomously or semi-autonomously; (ii) to provide the users (e.g., analysts) with reliable and actionable information products to conduct persistent surveillance missions; and (iii) to autonomously and/or remotely (re)configure and (re)task ISR assets to adapt to changing conditions and missions.

Topical areas and applications include (but are not limited to) the following:

- Interoperability for joint operations and coalition warfare

- Persistent ISR for current operations

- Data-to-decisions (D2D)

- Tasking, collection, processing, exploitation, and dissemination (TCPED)

- Collaborative information processing and sharing, and decision making among human-based and sensor-based systems

- Distributed/decentralized sensor networks and data fusion

- Novel ISR sensing for detection, tracking, and classification

- Unmanned ISR sensors and systems

- Persistent surveillance exercises, demonstrations, and lessons learned.

In 2013, the emphasis is on D2D, coalition interoperability, autonomy, and collaborative information processing and a number of sessions are dedicated to these topics. Here are some special and joint sessions:

- Special session and panel on the Science of Autonomy

- Special government session on ISR Interoperability

- Special NATO and Coalition sessions

- Joint session on Data-to-Decisions and joint panel on Decision-Driven Analysts with conference 8758: Next-Generation Analyst

- Joint session on Networking for Netcentric Warfare with conference 8754: Open Architecture/Open Business Model Net-Centric Systems and Defense Transformation 2013.

Tien Pham

Michael A. Kolodny

Kevin L. Priddy 
Proc. of SPIE Vol. $8742874201-12$

Downloaded From: https://www.spiedigitallibrary.org/conference-proceedings-of-spie on 26 Apr 2023 Terms of Use: https://www.spiedigitallibrary.org/terms-of-use 